7 (2016)

D0I: $10.18276 /$ rk.2016.7-03

Brigitte Schultze

Johannes Gutenberg-Universität Mainz

\title{
Hybridity Maintained, Reduced, Abolished and Redefined: The Czech Graphic Novel Alois Nebel (Jaroslav Rudiš, Jaromír 99, 2006) in Polish and German
}

\section{Introduction: Graphic Novel and cult figure}

The status of the Graphic Novel Alois Nebel in contemporary Czech cultural life is highlighted in the supplement to Literárni noviny of January 2015. The critic Radim Kopáč starts his article on "Czech comics at the peak" by stating that Jaroslav Rudiš and Jaromir 99 "with their trilogy Alois Nebel" had opened up "the path" (for comics) to the "broad [Czech] public" (Kopáć, 2015: 18). ${ }^{1}$ Alois Nebel, indeed a remarkable contribution to $21^{\text {st }}$ century comic, ${ }^{2}$ abounds in hybrid constellations and markers of hybridity. ${ }^{3}$ The German and the Polish versions of the Graphic Novel ${ }^{4}$ cannot but deviate from the intellectual, emotional and aesthetic sense contained in all these 'hybridities'. This study will try to outline the challenge to comparative studies contained in Alois Nebel and two neighbouring Middle European versions of this intermedial project. It will, however, not include the fourth volume, "At the track" (Na trati), first appeared in book form in 2008. Likewise, the scholarly literature

\footnotetext{
1 All translations from Czech, Russian and further languages - if not indicated otherwise - are mine B.S.

2 Introducing "The comics of the year", Thomas von Steinaecker states: "Every now and then, there is a comic redefining the rules of drawing and telling." (Steinaecker, 2014: 13).

3 This study follows my previous article (Schultze, 2015).

4 There may be further translations accessible by now. An English version could not be found.

5 This volume introduces additional personel and is - as concerns the distribution of pictures and narrative text - more in line with traditional comic literature. The German translation was done by another translator than the trilogy in 2013 (Rudiš, Jaromir 99, 2013).
} 
concerning the history of Czech comics ${ }^{6}$ and a host of specific topics, e.g. linguistic problems of comic literature, can only occasionally be included in this study. Specific attention will, however, be drawn to Alois Nebel as a cult figure. There is hardly any advertisement concerning Alois Nebel without mention of cult-status. For instance, Czech television announced the "inacted and drawn film" as "film adaptation of the cult comics Alois Nebel' (Alois Nebel, 2015); in 2012, the Czech Centres in Munich invited to an "Exhibition Alois Nebel" introducing the event as "comics" "about the melancholic railwayman, who has become a case of cult in Bohemia long ago" ("Výstava Alois Nebel v Mnichově"). With respect to cult-status, then, the transfer of the "melancholic railwayman" Alois Nebel into Polish and German can be a challenge to comparative studies. ${ }^{7}$ After all, Alois Nebel is not an icon of international and transcultural pop culture as, e.g., Batman, but a cult figure rooted, as will be shown, in Rudišs family traditions and in Czech historical experience. So there is a specific offer of personal identification for many Czechs. The presumable 'ingredients' of cult-status and the chances of communicating such contexts to recipients from other countries will have to be looked into.

In the following, the coming into being of the trilogy and main contents of the trilogy will be given in details necessary for comparative analysis; this will include some personal traits of the central character and narrator of the Graphic Novel (paragraph 2); a further paragraph (3) is devoted to the make-up of the Graphic Novel, including different types of paratext, and hybrid constellations as well as markers of hybridity in the source text; the central part of this study (par. 4) concerns the handling of markers of hybridity in both translations; problems of transplanting cult figure and cult-status will be considered separately (par. 5); final remarks concern possibilities of future research around Alois Nebel (par. 6).

6 A substantial contribution to the topic which might inspire experts in other countries is the encyclopedia of Czech comics (Déjiny českého komiksu 20 století, 2014). In his book report ("the most beautiful book of the year"), Jaroslav Císař emphasizes the exemplary editor achievement of this publication (Císař, 2015:14-15).

7 With respect to cult-status, comparative studies on a number of transmedial classics probably keep being desiderata. 


\section{A Middle European setting: between private experience of life and shared history}

Jaroslav Rudiš, an author, playwright, translator, journalist and amateur-musician, was born in Turnov (Eastern Bohemia) in 1972. Mainly "living and working between the Czech Republic and Germany" (Rudiš 2013b: 36/IV) and writing Czech and German, Rudiš has been cooperating with writers, theatre producers, musicians and painters for many years (cf. Schultze 2015). Transculturality and intermedialities, i.e. plenty of hybrid constellations, are markers of Rudišs activities. The same goes for his partner in the long-term project Alois Nebel-Jaromír 99, i.e. Jaromír Švejdík. Born in Jeseník (formerly Freiwaldau, Northern Moravia) in 1963, Švejdík works as painter and musician, writes texts (poetry) for the cultband Priessnitz (cf. Jaromir 99).

Appeared in single parts between 2003 and 2005 and in one volume in 2006 and 2011 (Rudiš, Jaromír 99, 2011), ${ }^{8}$ the trilogy Alois Nebel contains and reflects a certain portion of autobiographical material: handicapped by wearing glasses (and certainly also from other reasons), Jaroslav Rudiš could not make his passion for traditional Middle European trains and railways a profession. ${ }^{9}$ Two of his family members, however, his grandfather Alois, a pointsman, and an uncle, a station-master in Sudetenland, could serve as models for the railwayman Alois Nebel (cf. Mrazková, 2011: 30). Of course, the name of the central character and narrator is already a case of hybridity - in synchronic and diachronic perspective: the first name Alois (much less familiar to Northern Germans than to Bavarians), probably goes back to the Old High German noun "Alwisi" - 'the very Wise' (cf. "wisdom") ("Alois", 1978: 12). From German speaking regions, the name spread to Italy and further countries. The family name, "Nebel" ('fog', 'mist'), among others, refers to the railway man's personal fate and specific capacities: whenever fog falls down on the railway station, the man - haunted by trauma - starts visualizing and memorizing events from personal life and collective history. The "Nebel" triggering such memories also stands for a host of secrets (family secrets,

8 This source text is quoted in square brackets by the numbers of pages derived from the German edition.

9 The author's first novel, Nebe pod Berlinem (The Sky under Berlin, 2002), shows and reflects life in the German capital from the perspective of the system of local traffic, first of all the U-Bahn (underground trains). Cf. Schultze, 2015. 
personal deficiencies and errors) never elucidated throughout the novel. ${ }^{10}$ In a way, the family name implies an instruction for recipients. Active recipients may and should try to decipher some of the secrets in and behind the "fog". Being haunted by trauma, Alois Nebel has become a loner, satisfied with his job and his private passion - the collecting of old timetables. The hallucinations cause Alois' being taken to a lunatic asylum for some time.

Obviously in order to help recipients through the truly entangled content of the Graphic Novel, the blurbs of the different editions, including the translations, but also information spread on Internet, offer outlines of what is shown and told in every volume. This component of paratext ${ }^{11}$ will be given in full length, in a working translation close to the source text:

Bily' Potok ('White Brook', 'rivulet')

A small railway station in the Silesian mountains (Germ. Altvatergebirge), which trains cross to and fro, and the signals and platforms of which sometimes disappear in the mist [fog], hiding strangeness [oddness]. One lunatic asylum [Mental Home], the corridors of which people cross, for whom even these smallest train stations are a bit large, but in the mist they often see their end. One man, whom they call the Mute, since he even does not talk, when electric shocks are flowing through his head. After this he will listen more carefully.

Hlavni Nádraži (Main Station, i.e. Prague)

Someone wants to see the lighthouses on the Isle of Rügen, someone wants to order a coffee in Paris, and someone wants to see the prettiest railway station in Bohemia. Alois Nebel, the discharged narrator, who sees in the fog things others never see, comes to Prague. The building of the Main Station early uncovers its secrets. $\mathrm{He}$ tells himself that whoever goes away from here, will never return.

Zlaté Hory (Golden Mountains)

A forsaken [lost] railway line. Gold hidden under the mountains. Clouds filled with rain. A Polish murderer flying, in search of his father. The action shifts back to the mountains, where the dark past of Sudeten uncompromisingly is permeating with

10 A case of Indoeuropean etymological relationship is given by the fact that the German noun "Nebel" contains the Czech noun "nebe" ('sky', 'heaven') - at the same time an intratextual trace to Rudišs first novel Nebe pod Berlinem (cf. note 9). A further semantic dimension is opened up, when the family name is read backwards: the name likewise contains "Leben", i.e. 'life'.

11 The importance of paratext - so far not always considered adequately in comparative studies and comparative translation studies - is stressed by Jaroslav Špirk (Špirk, 2014: 19, 29, 144-147 passim). 
the present. Alois Nebel's life hit high water and finally also great love. The secret history [event] of the Mute comes to an end [is being completed]. ${ }^{12}$

The formula 'the action shifts back' (“Děj se přesouvá”) indicates a further case of inter- and transmedial hybridity in the Graphic Novel: a connection with the medium film. The medium film (maybe also television) is also implied in further information on the title page: "In the main role Alois Nebel" - "Theme and scenario Jaroslav Rudis" - "Theme and illustrations Jaromír 99". In a way, the vocabulary "illustrations" ("ilustrace") is playing with picture-text hybridity, since the genre comics, other than illustrations (changeable visual 'decoration', added to a text) (Schultze, Weinhagen, 2007: 1661) is based on interrelation and interplay between text and pictures (drawings), sometimes with a dominating role for the pictures. Play and humor around a host of hybrid constellations is, indeed, an aesthetic marker of the Graphic Novel Alois Nebel.

\section{Between past and present, geographical fixed points and open landscape, picture and text: cases of hybridity}

Different from many other Graphic Novels, the trilogy Alois Nebel does not count the pages. The missing of pagination may be interpreted as a case of hybridity between traditional comics counting pages and film based on different types of segmentation. ${ }^{13}$ The turns from one volume to the next are, so it seems, 'graphically mystified', so the trilogy appears as a whole. ${ }^{14}$ Next to artistic device of film, Jaromír Švejdík had gained "inspiration” from "American comics of the 50ies, socialist realism and motives of old scissor-cuts made in paper, still a typical form of popular artistry in Jeseník" (Alois Nebel). So Švejdík's inspirations themselves are a case of cultural mixture, i.e. of hybridity. Ethnical, cultural, linguistic and further hybridity is also given by Middle European past and recent past called to mind: concentration camps and holocaust, the expulsion of Germans from Bohemia and

\footnotetext{
12 These sketches of main content obviously play with mysteries and secrets throughout the action; at the same time, they predict openness between picture and text as aesthetic device in the trilogy.

13 The German version of Alois Nebel (Rudiš, 2014) uses pagination irregularly, so the pagination missing can be completed. This edition is quoted as D in square brackets.

14 Since I have the single volumes of the Polish translation at my disposal, there is a possibility of verifying the turns from volume to volume.
} 
Moravia at the end of the Second World War, the end of communism (1989/90) with dealers and criminals (Poles, Russians) profiting from the chaotic situation etc.

There are mainly four types of hybridity to be observed: intermedial hybridity (1), linguistic hybridity (2), graphic hybridity (3) and hybridity of discourse (4). In many examples, these categories overlap. A choice of examples may illustrate the amount of diversification and prepare comparative analysis between the source and both target texts.

(1) It is important to note there is a certain amount of pictures covering one or two pages with no text at all. Some of these black-and-white pictures indeed recall scissor-cuts. 'Intermedial information' is given by narrative text at the bottom of the page reflecting on what is to be seen on the picture, in pieces of dialogue, quoted thoughts, sign-boards within the pictures etc. A further variant of intermediality text and music - is brought to mind by one of Jaromír Švejdík’s poems, Nacht und Nebel (Night and Fog) texted and composed for the band "Priessnitz". In this instance, the name of the composer, Petr Kružík, replaces the medium music [337].

(2) The dominant type of linguistic hybridity consists in the basic Czech text combined with German, Russian, Polish, Slovak or English textual units. The frequency and diversification of Czech-German hybridity excels the other patterns. German is introduced in the beginning of the trilogy, when Alois - in sudden "mist" ("mlha") - sees two Nazi officers jumping down from a railway engine, shouting at him. The Nazi salute "Heil Hitler" is followed by two questions: "Wo ist deine Großmutter? Wo ist die rote Schlampe?" ('Where is your grandmother? Where is the red bitch?'); "Hast du Wasser?” ('Do you have water?' [19]). Alois admits he knows a little German. He shows the officers the water tap, so masses of wounded soldiers accompanied by nurses can come out of the train to get something to drink. Czech-German linguistic hybridity carries on the next two pages [20-21]. Pieces of memory and reflection reported by the disquieted railwayman are combined with pieces of German text - i.e. thoughts of single soldiers ("Scheißleben”, 'shit life') and of one of the nurses ("Er ist sympathisch. Wie mein Bruder." - 'He is likeable. Like my brother') and utterances articulated aloud: "Ich bin allein" ('I am alone'). The German text is given as a series of fotos.

When Alois' memories go back to the opening of the railway station (1888) and to his great-grandfather and grandfather who had already worked there, the sketch of a mountain range with German names ("Glaser Berg") and an excerpt from "Meyers Reisebücher" ('Meyers' travel books') informing about water-cures by "Doctor Prießnitz" in Freiwaldau and Gräfenberg illustrate the memories [42-43]. In the already mentioned lyrics by Jaromír Švejdík, the headline and the refrain 
are German - Nacht und Nebel, 'Night and fog [mist]' - the personal experience articulated is given in Czech [337]. Czech-German linguistic hybridity also occurs several times in connection with Auschwitz ("Arbeit macht frei” [257, 262]). ${ }^{15}$

Cases of Czech-Russian linguistic and graphic hybridity are to be observed in the beginning of the trilogy. When Alois mentions Russian (i.e. Soviet) soldiers in an old fortress getting munition and brown coal via his station, bits of small talk are being quoted: "Českie ženščiny cholodnye" ('Czech women are cold' [26]). Such pieces of dialogue are rendered in Cyrillic script. Another detail is the "Šašlik-train" from Irkutsk carrying goods for the celebration of the October Revolution. And Alois recalls Russian soldiers trying to escape from their army. One picture shows an almost bald-headed soldier looking out of the train-window, thinking to himself: "Prokljataja žizn”" ('Damned life' [29]). An escaped Russian, Volodja, who had found shelter on Alois' attic for a while, finally gets killed by his own people. Several cases of Czech-Russian hybridity, mainly small lexical units, are connected with this episode. ${ }^{16}$ Further examples are built on Czech-Russian linguistic hybridity in Latin script.

Since there are much less instances of Czech-Polish or Czech-Slovak, and even less of Czech-English hybridity, readers of the source text will be less challenged by this variant of language mix. For instance, when the Mute - suspected of having killed his mother - is taken to Kraków by a Polish police man, there is a sequence of short Polish texts: "Kwaśniewski, polska policja kryminalna” - "Czy ją zabiłeś??” ('Kwaśniewski, Polish criminal investigation' - 'Did you kill her??' [96]). English is, e.g., used when one of the drug addicts in the Medical Home is feeling himself as one of the "riders on the storm" [59]. Further linguistic and graphic hybridity is connected with Japanese [152-153]. A specific case are the inner-Czech varieties - literary, common and spoken Czech (cf. Schultze, 2015). In the beginning of the trilogy, the business-minded pointsman Wachek tells a friend on telephone he has organized pink-coloured, high octane petrol: "růžovej, vyoktanovej" [19]. It is impossible to communicate to target side readers Wachek is using the phonological variant "-vej" instead of "-vy". Further traces of linguistic hybridity could be named.

(3) Graphic hybridity is, first of all, given by Latin and Cyrillic script. The Japanese characters will probably be taken as part of the picture-based program. Graphic diversification also consists in alternation between black script on white ground (the dominant pattern) and white script on black ground, e.g. in several

\footnotetext{
15 See also pp. [137, 166, 197, 246, 251, 255, 260-262, 289-290 passim].

16 Cf. also pp. [25, 30-32, 135, 155, 164, 196, 212].
} 
German textual units [19-21, 43]. Graphic and linguistic hybridity are also used as comic device. For instance, Cyrillic script and Russian and English language are combined, when a Russian asks a taxi driver: "Glavnyj vokzal. Chau mač?" ('Main Station. How much?' [134]). There are different types of letters and letters of different size. Sometimes, such details can clearly be identified as aesthetic device. A further case of hybridity are pieces of Czech handwriting, e.g. a letter to the - imprisoned in Poland - Mute: "Milý pane Němý" ('Dear Mr. Mute' [178]). Here, translational transfer requires Czech-German (Czech-Polish) translation and the imitation of handwriting the way it used to be taught in Czechoslovakia - i.e. a rather specific variant of cultural transfer. Further cases of challenge stemming from graphic hybridity could be shown.

(4) Hybridity of discourse is similarly varied. Thus a choice of examples will have to suffice. Next to the reporting and telling by Alois, there are different types of oral discourse - interpersonal communication, pieces of "inner monologue", command shouted to soldiers etc. Among the contrastive forms of discourse are the letter to the Mute, Švejdík's lyrics (Nacht und Nebel) and the excerpt from the travelers' guide "Meyers Reisebücher". A specific case of hybridity is given by openness - connection respectively - between blurb (paratext) and the Graphic Novel itself: the short text giving the contents of the second volume ("Main Station") is partly contained in Alois' self-reflections in a train-compartment ('someone wants to see...' [121]). This play with categories of text can easily be overlooked.

\section{Transfer of hybridity in the German and Polish variants of Alois Nebel}

Since deviation from the hybrid constellations presented before is much more spectacular in the German than in the Polish version of Alois Nebel, the German version will be discussed first. With German as target language, reduction in the field of language diversity is inevitable. On a number of pages linguistic hybridity is abolished altogether. Especially relevant for the creation of intermedial, intellectual and aesthetic sense are the pages and double pages presenting Alois' visions and memories of the Second World War, i.e. trains with wounded German soldiers or entrances of concentration camps [D 20-21; 256-257]. The intermedial presentation based on linguistic hybridity - Czech, German - is definitely stronger in the Czech source text than the presentation in homogeneous German. This touches upon problems of aesthetics of effect (Germ. Wirkungsästhetik), i.e. on theoretical 
premises of comparative intermedial studies. Effect, it is known, is hard to measure and hard to define scholarly. A different mode of reception is, e.g., offered to German recipients when Alois remembers his great-grandfather and grandfather and the water-cures in Freiwaldau and Gräfenberg [D 42-43]. Alois' memories and the excerpt from "Meyers Reisebücher" verifying some of the memories are presented in homogeneous linguistic texture. So the handling of intermedial and linguistic hybridity, possibly combined with hybridity of discourse, may produce different effect for German recipients of single pages and double pages.

Intermedial transfer is specifically brought to attention, when the combination of picture and text going with a specific picture is not treated as invariant. ${ }^{17}$ In some instances, textual units going with a picture are left out. E.g., the Russian soldier's curse on life - "Prokljataja žizn"” ('Damned life') - is missing [D 29]. The recipient is free to invent what the soldier at the train-window may be thinking. A picture-text relation is changed into a picture without text, i.e. redefined. ${ }^{18}$ The omission of the Russian curse concerns coherence in the Graphic Novel: 'Damned life' resembles the German soldier's curse only seven pages before - "Scheißleben". Comparison brings to mind that plain soldiers experience service in the army quite alike.

The combination of interlingual and graphic hybridity - given by Russian in Cyrillic script - is mainly reproduced. There is, however, a difference in the graphic design of the characters. While the source text uses clearly different characters for Latin and Cyrillic (a type of 'fat' script for Cyrillic), the German translation standardizes Cyrillic script. ${ }^{19}$ This reduces the expressiveness of graphic hybridity. Next to omission and graphic deviation, there are also several deviations in the Russian text itself. For instance, in the source text, a Russian asks the taxi driver: "I čto Karel Gott?/ Germancy ego ljubjat" ('And how about Karel Gott? [how is he doing]/ The Teutons love him' [134]). The German version of Alois Nebel renders only one line: "I čto Karel Gott?" [D 135]..$^{20}$ This may be a case of self-censorship - to spare German recipients a bit of derision. It is important to note the German translation repeatedly reduces markers of derision and humor.

17 Comparative analysis of picture-literary transfer shows that the pictures are not always treated as invariants. This goes, e.g., for Wilhelm Busch's classic Max und Moritz in Polish translation. Cf. Schultze, Weinhagen, 2007: 1662-1663.

18 Small textual units of Russian and German are also omitted in other places, e.g. on pp. [134-135], cf. pp. [D 134-135].

19 Cf. pp. [31, 134-135] - [D 31, 134-135].

20 This line is given in an appendix in German translation - "Was macht Karel Gott?", together with further Russian text in German translation [D 359]. So 'moderate' pagination may have been chosen because of this help for German recipients of Alois Nebel. 
With respect to graphic hybridity, specific challenge is connected with the hand-written documents, e.g. the letter to the Mute. The reproduction of the letter ("Lieber Herr Stumm" - 'Dear Mr. Mute' [D 178]) shows an attempt at rendering careful handwriting. The typically Czech tradition, however, is not called to mind.

Hybridity of discourse is most strikingly neglected through omission of Švejdík's lyrics, i.e. the song Nacht und Nebel. An empty page [D 337] stands for the text plus copyright information and a piece of Czech text repeating the beginning of the song - "My personal vampire...". So next to hybridity of discourse, the genre of poetry in the Graphic Novel, a case of intermedial hybridity is likewise abolished. The opposite side of the source text [336] shows a railway-track with two waggons on it and two clouds with a goodbye in rhymes ('Station-master...'). These omissions affect the transmedial project Alois Nebel as such: they fade out music, i.e. the band Priessnitz; ${ }^{21}$ they also fade out some of the 'real life' - context of the Graphic Novel.

The first Polish edition consists of three separate volumes published in 2007 (Rudiš, Jaromír 99, 2007). ${ }^{22}$ Every volume has a cover-text summarizing main content, but also an additional page introducing the series "Biblioteka Centrali" devoted to the "Art of comics in Middle Europe". Besides, there is extensive further paratext going with every volume - informing about life and works of the team Rudiš/Švejdík, the main scene of action at the Czech-Polish border, Polish personel in the Graphic Novel. Recipients acquainted with these accompanying texts will probably more easily find access to the hybrid fabric of Alois Nebel, than recipients of the German edition. Of course, the Polish translator is in a privileged position. Besides having to translate mainly oral discourse between two West Slavic languages the reduction of linguistic hybridity is rather limited, since there are only a few Polish 'micro-texts' in the original. The same goes for Czech-Slovak linguistic hybridity when transferred into Polish. In the source text, a gypsy woman wants to tell Alois' fortune: "Pánko, chcete poznat' osud?" ('Mr., do you want to know [your] fate?' [131]. This and further pieces of partially faulty Slovak are rendered in Polish: “Chce poznać swój los?” ('Want to know your fate?' [P 131]). ${ }^{23}$

\footnotetext{
21 The relevance of music is also stressed by a short note in the blurbs: "Alois Nebel recommends listening to the songs of the band Priessnitz while reading this book." This recommendation concerning 'three media hybridity' (text, picture, music) is omitted in the German and Polish translations.

22 These volumes are quoted as $\mathrm{P}$.

23 The encounter with the gypsy woman belongs to the relatively rare cases of deviation from the content of the source text: the woman wants to sell a golden wrist-watch from the vicinity of "Bratysława" [P 131].
} 
On the whole, the Polish version of Alois Nebel is remarkably close to the source text. There is no deviation from intermedial hybridity, i.e. by omission of pieces of text going with one or the other picture. German, Russian and further words or phrases are reproduced in accordance with the graphic make-up of the source text. Polish recipients are expected to help themselves with linguistic and graphic hybridity, i.e. there is no appendix with translations of Russian text. Sometimes, spelling and phonetic diversification are played off against one another. Such creative transfer may function as comic device. E.g., while the source text renders a command (probably the words of a taxi driver) as "Hundert Mark. Sofort" [137] in correct German spelling, the Polish translation chooses phonetic transfer: "Hundert mark. Zofort" [P 137]. Linguistic hybridity is reproduced in a way it can also be heard. This strengthens the case of transmediality.

A specific case are the handwritten documents, e.g. the letter to the Mute. The Polish version of Alois Nebel replaces the handwritten letter by a text written on computer, in Zapf Chancery, i.e. written in characters different from the dominant design (Arial/Helvetica). So graphic diversity is maintained [P 178]. While the Czech letter is written somewhat clumsily, even with a deletion, the Polish version is a 'neutral' computer text - of course, imitating handwriting - with no graphic markers of personal endeavour - and no markers of 'Czechness' at all. So with a few exceptions, Czech and Polish recipients are confronted with remarkably similar hybrid constellations.

\section{Cult-status of Alois Nebel and comparative studies}

Though the cult-status of Alois Nebel is repeatedly claimed in personal conversation, on several Internet platforms, in exhibitions etc., there has been, so it seems, no attempt at putting together possible reasons for this status. ${ }^{24}$ Obviously, cult and fan communities are more connected with Tomáš Luňák’s animation film (2011) and activities on Internet platforms than with the trilogy looked into here (cf. Jakeschová, 2012: 1, 40-43, 58 passim). Of course, one has to distinguish between presumable reasons and incentives for cult-status and cult as it is produced and commercialized via media and in the media (Jakeschová, 2012: 22-58). Both aspects no doubt, overlap. Though the creators Rudiš and Švejdík have done much to make their Graphic Novel a success - nationally as well as internationally - the cult has been

24 In private conversation the phenomenon is affirmed as existing, however, not explained. 
developing further independently from the creators (Jakeschová, 2012: 9). These are the conditions of a globalized, 'medialized' world. Letting aside such wider horizons, among the presumable reasons for the specific national (Czech) and international success of the trilogy Alois Nebel are: 1. an extraordinarily impressive variant of an anti-hero, i.e. one of the characteristic figural patterns of comic literature. In a world of personal and historical-political faultiness and crime, he has a sense for right and wrong; while others are moved to make money and get ahead, the unambitious Alois longs for steady, reliable living conditions; in a world of permanent acceleration and global mobility, he identifies himself with his work on a traditional - 19th century - railway station. This may fascinate many recipients. 2. Alois Nebel's railway station is a symbol of $20^{\text {th }}$ century Middle European individual and collective history; to some extent, this also goes for Prague's Main Station. 3. In appealing to the recipients' intellectual and emotional capacities and intermedial curiosity and competence, the Graphic Novel is a remarkable achievement among hosts of examples of the genre. 4. The trilogy asks for recipients' attitudes different from attitudes expected by most comic literature. Recipients have to pause, re-read picture and text etc. Some pieces of picture-textual intermediality recall the theoretical concept of difficult form (Germ. erschwerte Form) of the Russian Formalists. So there are many reasons for international success.

With respect to comparative studies, it is important to note there are also elements strictly connected with Czech traditions (the literary repertory) and Czech self-perception. E.g., Alois Nebel recalls the tradition of Czech anti-heroes - Hašek's Švejk, Hrabal's Miloš Hrma in Ostře sledované vlaky (Sharply controlled trains) and others. ${ }^{25}$ Another case are self-ironic hints at the Czech's presumed unwillingness to go abroad. The phrase "Someone wants to see the lighthouses on the Isle of Rügen" quoted in the blurbs stems from Alois' reflection during his trip to Prague. ${ }^{26} \mathrm{Never}$ having wanted to go further than Prague, Alois is an embodiment of this "being afraid of moving" ${ }^{27} \mathrm{~A}$ further case of self-irony is the habit of drinking beer. Some of the culture-bound elements will probably not be detected by non-Czech recipients.

\footnotetext{
25 Hrabal is alluded to several times, e.g., when Alois, standing in a toilet of the Prague railway station, thinks to himself: "Hrabal should see this" [148].

26 This hybrid constellation between main text and paratext is not reproduced in the Polish and German translations.

27 This case is highlighted in Rudišs novel Grandhotel. Cf. Schultze, 2015.
} 


\section{Conclusions}

This, so it seems, first attempt at analyzing hybrid constellations in the Czech Graphic Novel Alois Nebel and in the German and Polish translations shows tremendous challenge for comparative translation analysis ${ }^{28}$ and for comparative studies as such. Concentrating on four types of hybridity - intermedial, linguistic and graphic hybridity and hybridity of discourse - the study reveals remarkable differences in some of the transfer solutions. While the Polish target text, on the whole, maintains the basic features of source text hybridity, the German translation chooses a number of deviations hard to explain. This, e.g., goes for the wiping out of intermediality through elimination of pieces of text.

This study, however, is only a beginning. Comparative analysis could and should go much further. Comparative analysis, e.g. could have included the handling of inner-Czech linguistic hybridity (the varieties, German-Czech language mix), transfer of the linguistic texture of comics, of film narration and further components within hybridity of discourse. The actual (2015) boom of Graphic Novels given, ${ }^{29}$ scholars might try to situate this Czech contribution to the genre in international context. Such a task can probably only be coped with by a team of experts.

Among challenge for comparative literature and comparative studies, no doubt, is the question if and how some of the aesthetically functional material can be defined as international, transnational etc. on the one hand and national, regional on the other hand. A further question concerns reading (linguistic), cultural and intermedial competence of average recipients, scholars and translators of the Graphic Novel Alois Nebel. ${ }^{30}$ Considering the specifically rich graphic program, individual scholars may be asked too much, i.e. some types of problems may have to be tackled in team work. Actual and future comparative studies clearly ask for more collective endeavour than traditional topics for comparative literature.

28 Out of consideration for the length of this study, some of the results of comparative analysis were not included in the presentation.

29 In connection with a collection of "Actual Graphic Novels from Germany" presented at the Frankfurt Book Fair (Frankfurter Buchmesse) 2014, the Goethe-Institut Krakau had organized an exhibition of Graphic Novels and posters - Graphic Novels. Spotkania z komiksem Niemieckim (Graphic Novels. Encounters with the German comics), 04.03-30.04.2015. Cf. "Tylko to, co najlepsze".

30 New perspectives might be gained by comparative analysis of translations into English and French, should they be available. 


\section{Works cited}

"Alois". In: Taschenbuch der Vornamen. München: Humboldt-Taschenbuchverlag Jacobi KG, 1978.

Alois Nebel. http://www.ceskatelevize.cz/porady/10201964112-alois-nebel/ [download: 19.01.2015].

Císař, Jaroslav. "Dějiny českého a slovenského komiksu." Literárni noviny. Biblio 5 (14.04.2015): 14-15.

Déjiny českého komiksu 20 století. 1-2. Tomáś Prokůpek, Pavel Kořínek (main eds.), Martin Foret, Michal Jareš (eds.). Praha: Filip Tomáš - Akropolis, 2014.

Jakeschová, Jana. "Alois Nebel" jako transmédiálni kulturni fenomén [Alois Nebel as transmedial cultural phenomenon]. Brno: Masaryková Universita, 2012.

Jaromír 99. https://www.google.de/?gws_rd=ssl [accessed: 19.01.2016].

Kopáč, Vadim. "Český komiks na vrcholu." Literární noviny. Biblio 3 (15.01.2015): 18-19.

Mrazková, Tereza. Deutsch-tschechische Begegnungen im Werk von Martin Becker und Jaroslav Rudis [German-Czech encounters in the works of Martin Becker and Jaroslav Rudiš; Czech B.A.-Thesis]. Prag: Karlsuniversität, 2011.

Rudiš, Jaroslav. Jaromír 99. Alois Nebel. Kreslená románová trilogie [A drawn novel-trilogy]. Praha: Labyrint, 2011.

----. Alois Nebel. Leben nach Fahrplan [Life after timetable]. Aus dem Tschechischen von Mirko Kraetsch. Dresden, Leipzig: Voland \& Quist, 2013.

----. Alois Nebel. Aus dem Tschechischen von Evá Profousová. Dresden, Leipzig: Volland und Quist, 2014.

---. Alois Nebel. Biaty Potok. [2:] Dworzec Gtówny. [3:] Ztote Góry. Powieść Graficzna. Przekład polski Michał Słomka. Poznań: Zin Zin Press, 2007.

Rudiš, Jaroslav. Zapisuju si do notesu ukradené dialogy [I note down in my notebook stolen dialogues]. Lidové noviny (6.04.2013): 36/IV.

Schultze, Brigitte. "Hybrid constellations and national authorship: prose fiction by Jaroslav Rudiš (2002-2013) and Olga Martynova (2013).” Rocznik Komparatystyczny - Komparatistisches Jahrbuch 6 (2015): 69-90.

Schultze, Brigitte. Weinhagen, Beata. Kinderliteratur und pikto-literarische Intermedialität: Translatorische Variantenbildung an Wilhelm Buschs "Max und Moritz" [Children's literature and picture-literary intermediality: The formation of translational variants to Wilhelm Busch's Max und Moritz]. In: Harald Kittel et al. (eds.): Übersetzung. Translation. Traduction. Ein internationals Handbuch zur Übersetzungsforschung 2. Berlin, New York: Walter de Gruyter, 2007. 1660-1669.

Steinaecker, Thomas von. "Die Comics des Jahres". Süddeutsche Zeitung 299 [30.12.2014]: 13 . 
Špirk. Jaroslav. Censorship, Indirect Translations and Non-Translation. The (Fateful) Adventures of Czech Literature in $20^{\text {th }}$-century Portugal. Newcastle upon Tyne: Cambridge Scholars Publishing, 2014.

"Tylko to, co najlepsze" [Only the best]. Cracow supplement to Gazeta Wyborcza (4.03.2015): $1-4$.

"Výstava Alois Nebel v Mnichově". http://www. czechcentres.cz/novinky/mnichov-alois-nebel/ [accessed: 19.01.2015].

Hybridity Maintained, Reduced, Abolished and Redefined:

The Czech Graphic Novel Alois Nebel (Jaroslav Rudiš, Jaromír 99, 2006) in Polish and German

\section{Summary}

This study is devoted to comparative analysis of hybridity in Jaroslav Rudišs and Jaromír Švejdík's Graphic Novel Alois Nebel - the trilogy in book-form, 2006 (2011) - and the Polish and German translations. The basic forms of hybridity are intermedial (picture and text) hybridity, linguistic hybridity (given by elements of German, Russian, English, Polish and Slovak together with Czech main text), graphic hybridity (between Latin and Cyrillic script, printed and hand-written characters), and hybridity of discourse (interpersonal communication, telling, personal reflection, non-fiction text etc.). While the Polish text - privileged by translation between two West Slavic languages - maintains most of the cases of hybridity, the German translation chooses more deviation, e.g. by occasionally eliminating pieces of text. Further cases of interest are cult-status and context and aesthetic markers transculturally accessible, but also detail only to be taken in by Czechs.

Keywords: comparative literature, translation studies, intermediality, Graphic Novel, hybrid constellations in Middle Europe, Jaroslav Rudišs, Jaromír Švejdík

Słowa kluczowe: literatura porównawcza, translatologia, intermedialność, powieść graficzna, hybrydowe konstelacje w Europie Środkowej, Jaroslav Rudiš, Jaromír Švejdík 